\section{From a differential diagnostic analysis and therapeutic approaches to cervical myelopathy successful surgical treatment - case report}

Dragoslava Jovanovic

Department of Neurology CHC Zemun, Belgrade, Serbia

\section{Apstrakt}

The aim of this case study is to, by analysis of its clinical picture and course, as well as available courses of treatment, emphasize the importance of pathological entity of cervical myelopathy secondary to cervical vertebrae degeneration, as well as the possibility of a successfull surgical procedure as first choice of treatment. We have analyzed the sum of medical history information, neurological examination findings and its development and the results provided by diagnostically techniques - magnetic resonance, evoked potentials, immune-serological findings as well as findings of lumbar puncture. In our case study we have a patient with a sudden and progressive onset of clinical picture of spastic quadriparesis, primarely on its lower extremities. The conducted clinical investigation resulted in indentifying the underlying pathological substrate to be cervical myelopathy due to changes in cervical spine. Operative treatment was favoured as a course of action, with a successfull outcome, provided by the follow-up of patients physical rehabilitation and its neurological status. This case study presents an illustration of a favourable outcome of surgical treatment of cervical myelopathy on the ground of degenerative spondilotic changes of cervicale spine. It presents a confirmation that this method is still irreplaceable in treatment of this particular neurological and orthopaedical pathology. It is a method of first choice in creating a chance for, if not improving a patients' functional state than at least stopping the advance of pathological process and inevitably its clinical course, that is a progression of neurological deficit.

Ključne reči: cervical myelopathy, surgical treatment, cervical vertebrae degeneration

\section{Od diferencijalno dijagnostičke analize i terapijskog pristupa cervikalne mijelopatije do uspešnog hirurškog lečenja}

\author{
Dragoslava Jovanović \\ Služba neurologije, KBC Zemun, Beograd. Srbija
}

\section{Abstract}

Cilj ovog prikaza slučaja je da na osnovu analizirane kliničke slike i raspoloživog ciklusa lečenja istakne značaj patološkog entiteta sekundarne cervikalne mijelopatije kao posledica degenerativnih spondilotičnih promena na cervikalnim pršljenovima. Ujedno, cilj je bio da se istakne značaj hirurškog tretmana, kao metoda prvog izbora u procesu uspešnog lečenja. Mi smo analizirali sveobuhvatne podatke iz medicinske dokumentacije, rezultate neuroloških kliničkih i dijagnostičkih ispitivanja: evocirane potencijale, rezultate lumbalne punkcije, imuno - serološke nalaze i rezultate magnetne rezonance. Pretstavljen je pacijent sa naglo nastalom i progresivno razvijenom kliničkom slikom kvadripareze, prvenstveno na donjim ekstremitetima. Sprovedenim kliničko dijagnostičkim ispitivanjem dobijeni su rezultati koji su ukazali na sekundarno nastalu cervikalnu mijelopatiju, na terenu degenerativnog procesa na cervikalnom regionu. Operativno lečenje je bio izbor i metoda lečenja koja se pokazala kao dobar izbor sa uspešnim ishodom. Krajnji ishod lečenja je bio upotpunjen adekvatnom fizikalnom rehabilitacijom. Ova prikaz slučaja predstavlja ilustraciju povoljnog ishoda hirurškog lečenja cervikalne mijelopatije na terenu degenerativnih spondilotičnih promena cervikalne kičme. To je metoda prvog izbora u poboljšavaju funkcionalnog statusa pacijenata i ujedno način da se zaustavi napredovanje patološkog procesa i neurološkog deficita pacijenata.

Key words: cervikalna mijelopatija, hirurški tretman, degeneracija vratnih pršljenova 


\section{Introduction}

Cervical myelopathy represents a unique name for a group of syndromes that result from dysfunction of the spinal cord. The causes are numerous, but spondylosis at one or more levels of the spine is the most common etiology in terms of degenerative changes of the spine. These spondylotic changes can lead to compression and ischemic dysfunction ${ }^{1,6,9}$. Cervical spondylotic myelopathy as a result of spinal stenosis has become even more prevalent in older age groups of the general population ${ }^{8}$. The clinical course of the disease is variable, usually with a picture of a slow deterioration of functional, very often in the early stages of clinically manifest disease, sensory symptoms at the level of conscious or superficial, often, deep sensibility, to appear, without exception, with the progression of the disease, spastic paraparesis or quadriparesis with varying degrees of weakness of foot or hand weakness, with the disorder posturalnosti and sphincter control ${ }^{3,4,9}$.

In this case report, we discuss the young person who is in the department of neurology of our hospital due to some problems in terms of difficulty in walking, according to the type of spastic paraparesis, with aggravated sphincter control, soon beginning three weeks prior to hospitalization, distinctly progressive character, of unknown etiology, vague potential driver factors (injuries, infectious / inflammatory processes, etc., positive family history).

\section{Case report}

The patient, aged 39 years, was hospitalized in the department of neurology by the symptoms of trouble walking. Problems started around three weeks prior to hospitalization, where the patient start problems associated with the physics of effort, after which the symptoms began, shuffling gait with the observed progressive deterioration, with the occurrence of urinary incontinence, as well as nonspecific complaints during defecation, which is described as the inability to activate musculature as early as possible. About a month before the onset of symptoms was cold. Her medical history revealed that in April the same year, or about two and a half months before the onset of symptoms fell from the engine, then was verified fracture of the clavicle, with immobilization, on this occasion, without having pain in the spine, loss of consciousness, head injury. The personal history no data on chronic diseases. Without a positive family history. On receipt of somatic findings. The neurological findings on cranial nerve findings in general neat, free neck, spinal column with no signs of deformity, can move freely in all directions, Lermitteov positive sign, spasticity of the right hand with weakness of flexion and extension of fingers IV and V (GMS 4/5), MTR symmetric, increased, reflex flexor of fingers bilaterally positive, spastic leg elevated tone, MTR symmetrical, boosting, right positive Babinski's sign, the level of sensitivity to Th6 for feeling fine touch, vibration sensibility truncated to the left knee, the right to iliacae anterior superior spine, and cerebellar rehearsals on the legs and ataxia dismetrija both sides, positive Romberg with and without controls vision, spastic gait paraparetičan, inability to walk on heels and toes, occasional incontinence of urine. Admission diagnosis: Triparesis spastic. Laboratory analysis in the normal range, with no signs of an inflammatory syndrome., Vitamin B12 neat, tumor markers were negative. CT neat, ultrasound of the abdomen and lung X-ray normal, X-ray of the spine is indicated in degenerative changes of the cervical spine with unkartrotične and spondylotic changes, minor degenerative changes in the vertebrae of the thoracic and lumbosacral spine. We performed a lumbar puncture with immunoserological tests: physical and biochemical findings liquor neat, histopathologic findings sediment liquor neat, immunoelectrophoresis and electrophoresis neat, tidy imunoglobilna level, tests on B.burgdorferi and T.pallidum neat, tidy virology, autoantibody negative, it proved the presence of LA negative finding of LE cells. In the ward treated with pulse corticosteroid therapy of methylprednisolone $1000 \mathrm{mg} /$ day, to which there is a slight improvement of neurological findings, with slightly improved walking, with lower levels of sensitivity with Rh6 level Th7Th8. Patient discharged after two weeks in order to re-hospitalized MRI of the cervical and thoracic spine. In the meantime, there is a change in the neurological examination: the patient now states the level of sensitivity in the region of the Th12-L1, MTR are more pronounced on the right leg, right leg hypoesthesia, vibratory sensibility is left neat, right truncated to the level of the processus xiphoideusa, cerebellar probe properly performed, stroke in a slight improvement.

MATERIA MEDICA • Vol. 30 • No. 3・ septembar 2014. 
MR endocranium MRI of the thoracic spine indicated the presence of a slightly lower height diameter Corps Th7 field Schmorl hernia, while MRI of the cervical spine demonstrated marked degenerative changes in the vertebral bodies, intervertebral disc and joints, and intervertebral disc protrusion - dorsomedial along the circumference at the level of $\mathrm{C} 4 \mathrm{C} 5$, pronounced paramedijalno right, paramedijalno bilaterally, slightly more pronounced on the left at the level of C5-C6 and paramedijalno both sides, more on the left at the level of C6-C7 with propagation in the corresponding intervertebral foramen, perform moderate protrusion protrusion dural sack, with narrowing of the anterior spinal space, compressing associated nerve roots in the lateral recesses and intervertebral foramen obsotrano, predominantly C5, C6 and C7 bilaterally, slightly more pronounced on the left, with compression of the spinal cord and subsequent myelopathy at the level of C5-C6 and smaller portion of C4-C5.

Consulted a neurosurgeon who, before a final decision on further treatment, from a differential diagnostic reasons advised to do endocranial MRI and MR angiography.

The patient was hospitalized for this reason and for the third time, ten days later, MRI and MRA endocranium endocranium were normal, with rare microangiopathic changes in frontal bilaterally. Neurological examination findings on cranial nerves normal. In the hands of spastic muscle tone discreetly raised in his right hand, weakness of flexion and extension of fingers IV and V bilaterally, right more and more extensions, $4 / 5$ flexion, extension 3-4 / 5, MTR reinforced, symmetrical reflexes flexor of fingers to the right, vibratory sensibility referred to as reduced to the level of the elbow, symmetrical, elevated on legs spastic muscle tone, more right, more difficult fixation, MTR amplified, symmetric, plantar response right positive Babinski, left, is atypical, the level of sensitivity th12-L1, vibratory sensibility is off to the processus xiphoideusa in cerebellar rehearsals dismetrija mild degree of both sides, more on the right. Romberg positive, spastic gait paraparetičan without progression. Discharge diagnosis: Quadriparesis pp spastic paraparesis, Myelopathia cervical compressive cum polidiscopathia C4-C5 et C6-C7.

Advised the patient to make an appointment with a neurosurgeon doing reviews on surgical treatment. The patient was hospitalized at the end of the same month at the Department of Neurosurgery, Clinical Center of Serbia for decisions on further treatment because of neuroradiological presentation of cervical polidiskopatije, canal stenosis and resultant myelopathy. Underwent surgery Disectomia ventralis, implantatio cage No. 7. The postoperative course was uneventful and subjective symptoms and neurologic deficits in light regression. The patient was sent away on extended physical rehabilitation in stationary conditions.

One month after surgery were done evoked potentials. VEP showed normal findings, AEP is shown next to flattened response IV and V waves, right extended response between the first and third waves, with the median nerve SEP showed minimal extended response of the cervical spine with bilateral absence of cortical responses.

On neurologic examination, after completion of physical rehabilitation, was a notable improvement in neurological findings - findings on cranial nerves and neck neat, tidy the hands of GMS, MTR amplified to the arms, in the anti-gravity rehearsals proper fixation of the hand, without sinking, MTR on your feet enhanced, plantar response is flexion, leg elevation possible 70 to 60 degrees, independent mobility, gait in spastic paretičan lesser extent, neat walk on heels and toes.

\section{Discussion}

The patient in our case was hospitalized for diagnostic tests etiological causes of spastic paraparesis. The diagnostic test was found to be basically comes cervical myelopathy as a result of degenerative changes of the cervical spine and compression effects on the cervical spinal cord with confirmed mijelopatskim signal on MRI as an evidence of a spinal cord injury ${ }^{1,4,5}$.

Degenerative changes of the cervical spinal cord injuries are a common cause of cervical myelopathy ${ }^{1}$, usually accompanied by a clinical picture of spastic paraparesis and sphincter control disorders, as the dominant symptoms. Such symptoms were present in the patient, and in our case. Due to the localization of the process and the associated nervous structures in the cervical spinal cord, neurosurgical treatment is very risky method of treatment ${ }^{18,19}$. Surgical treatment is usually recommended to improve patient symptoms and prevent exacerbation ${ }^{2}$.Therefore, in most cases, the initial approach, with exceptions on a case-by- 
case basis depending on the severity and changes in the spine or spinal cord at the time of diagnosis, and monitoring of the patient and the first line of conservative methods of treatment, symptomatic or supportive towards therapy and physical therapy ${ }^{16,17}$. However degenerative changes of the cervical spine are by nature pathogenesis of progressive character which eventually gives rise to a damaged cord or progression of images of cervical myelopathy ${ }^{8,9}$. This makes it necessary not to say inevitable, unless there are contraindications second nature, as is often the case in elderly patients due to associated co-morbidities, disease at some point consider operating a therapeutic approach as the only possible long- term and potentially effective method of treatment ${ }^{15}$. What makes our case interesting is that it comes to a young person with no predisposing risk factors, genetic or environmental factors with at the time of diagnosis, severe degenerative changes of the spine and pronounced symptoms.

We believe that a traffic accident that the patient suffered two months before the onset of symptoms difficult to put into context clarified the pathogenesis of the patient's problems and that, at best, over the possibilities of indirect lesions of the cervical spine or spinal cord, could have only an indirect effect on the potentiation of accelerating development of manifest clinical symptoms would be, it is certain, and rapidly developed itself. Application of conservative therapy or pulse corticosteroid therapy, gave only short-term effects of limited extent. In view of the foregoing, the patient, otherwise good general health, with advanced changes of the spine and the clinical findings, with some rapid progression of symptoms over time, a decision was made on surgical treatment, as well as the first direct election method of treatment ${ }^{7,10}$. Of course, the risk linked with this kind of operation is large, or if the patient was found in the specific assessment of the risks of surgery versus the potential benefits of the surgery, with a picture of a certain progression of symptoms over time, with an increasing risk that the surgery carried with him if be postponed. In our patient, the choice fell on the anterior cervical decompression and fusion ${ }^{5,12}$, which is one of the most common operating procedures specific to the mentioned pathology, given that cervical myelopathy in most cases resulting from compression of the spinal cord as a result of pathological changes in the cervical region of the front of the spinal cord ${ }^{13,14}$. In addition to these procedures are often used and adapted by laminectomy, so-called. laminoplastic. Which of these two methods will be the method of choice depends primarily on the specifics of the patient's anatomy. Anterior cervical decompression has three important advantages over laminectomy $y^{5,10}$ :

1. Directly removing the front causes a localized compression of the spinal cord without manipulation of the spinal cord or spinal nerve roots ${ }^{11,12}$

2. The stabilization of the spine by fusion, eliminating movement and the development of further degenerative changes in the operative level of the spine ${ }^{16,17}$.

3. In general, the less pronounced pain syndrome, operative approach is performed dissection along the plane of the tissue, not punching muscle as is the case with, for example, posterior cervical approach ${ }^{17,18,20}$.

As for the results, generally the largest number of surgical series is a considerable improvement in most patients, given that the surgery was performed before the onset of irreversible spinal cord injury. In the worst cases, surgery can remove the source of spinal cord injury and stop the progression of the disease in stunned stage. The prognosis is generally proportional to the degree of compression of the spinal cord, where the course progressed cases have a worse prognosis. Therefore, timely surgery may play an important role in determining the final outcome of the disease.

Surgery and immediate postoperative course were duly passed, which was followed by physical rehabilitation. Evoked potentials, made a month after the surgery they gave us early objectification of improving the situation, along with the finding that, of course, showed the pathological consequences of early lesions of the cervical spinal cord. Further confirmation of the positive outcome of the surgery gave us a neurologic findings after physical rehabilitation showed significant improvement compared to the preoperative period.

MATERIA MEDICA • Vol. 30 • No. 3・septembar 2014. 


\section{Conclusion}

Studies have shown variable clinical course of individual entities in this group, with progressive neurological deterioration in most patients. Although prospective comparative study actually scarce, the existing literature suggests that surgical treatment is the only reliable method that helps to stop the progression of myelopathy and may lead to functional recovery in many patients. The selection of the surgical procedure must be carefully individualized view based on specific clinical and radiological factors.

While procedures for anterior decompression and fusion in one or two segments give good results at three or more levels are associated with increased morbidity ${ }^{19}$. New techniques for the treatment of cervical myelopathy at multiple levels including anterior decompression with fusion of 360-degree hybrid corpectomi, anterior cervical fusion disectomi and techniques into use and dynamic anterior cervical implants, as well as laminoplastic.

This case is illustrative of a favorable outcome of the surgical treatment of cervical myelopathy as a result of degenerative changes in the spine and spondilotičnog confirm that this method of treatment is still irreplaceable in creating chances for securing if not improve the situation, at least stopover pathological processes and otherwise inevitable progression of further clinical picture disease or progression of neurological deficit ${ }^{15,16,17}$.

\section{Literatura}

1. Darren R. Lebl, MD, Hughes A, Cammisa FP, O’Leary PF. Cervical Spondylotic Myelopathy. Pathophysiology, Clinical Presentation, and Treatment HSS J. 2011;7(2):170-178.

2. Sumi M, Miyamoto H, Suzuki T, Kaneyama S, Kanatani T, Uno K. Prospective cohort study of mild cervical spondylotic myelopathy without surgical treatment. J Neurosurg Spine. 2012;16(1):8-14.

3. Ropper HA, Samuels AM. Adams \& Victor's Principles of Neurology, 9th edition, The McGraw-Hill Companies, Inc., 2009.

4. Bradley G. Walter, Daroff B. Robert, Fenichel M. Gerald, Jankovic Joseph. Neurology in Clinical Practice, 5th edition, Butterworths Heinemann Elsevier, Philadeplhia, SAD, 2008.

5. Goetz Christopher G.Textbook of Clinical Neurology, III ed., Saunders, 2007.

6. Lewis PV. Merritt's Neurology, 11th edition, Lippincott Williams \&Wilkins, 2005.

7. Matz PG, Holly LT, Mummaneni PV, Anderson PA, Groff MW, Heary RF, Kaiser MG, Ryken TC, Choudhri TF, Vresilovic EJ, et al Anterior cervical surgery for the treatment of cervical degenerative myelopathy. J Neurosurg Spine. 2009; 11(2):170-3.

8. Mumenthaler Mark, Heinrich Mattle, Taub Ethan.Fundamentals of Neurology, Thieme, Stuttgart, Germany, 2006.

9. Wen CY, Cui JL, Mak KC, Luk KD, Hu Y. Diffusion tensor imaging of somatosensory tract in cervical spondylotic myelopathy and its link with electrophysiological evaluation. Spine J. 2014;14(8):1493-500

10. Ha EJ, Lee SE, Jahng TA, Kim HJ. Cervical Compressive Myelopathy due to Anomalous Bilateral Vertebral Artery. J Korean Neurosurg Soc. 2013;54(4):347-9.

11. König SA, Spetzger U. Surgical management of cervical spondylotic myelopathy - indications for anterior, posterior or combined procedures for decompression and stabilisation. Acta Neurochir (Wien). 2014;156(2):253-8

12. Kobayashi H, Kikuchi S, Otani K, Sekiguchi M, Sekiguchi Y, Konno S.BMC Development of a self-administered questionnaire to screen patients for cervical myelopathy. BMC Musculoskelet Disord. 2010;11:268

13. Chang V, Holly LT. Controversies in the management of cervical spondylotic myelopathy. J Neurosurg Sci. 2013 Sep;57(3):241-52.

14. J Am Acad Cervical spondylotic myelopathy: diagnosis and treatment. Orthop Surg. 2001;9(6):376-88.

15. Geck MJ, Eismont FJ Surgical options for the treatment of cervical spondylotic myelopathy.Orthop Clin North Am. 2002; 33(2):329-48.

16. Meyer F, Börm W, Thomé c. Degenerative Cervical Spinal Stenosis - Current Strategies in Diagnosis and Treatment, Dtsch Arztebl Int. 2008;105(20): 366-372. 
17. Sevki K, Mehmet T, Ufuk T, Azmi H, Mercan S, Erkal B. Results of surgical treatment for degenerative cervical myelopathy: anterior cervical corpectomy and stabilization. Spine (Phila Pa 1976). 2004;29(22):2493-500.

18. Naderi S, Ozgen S, Pamir MN, Ozek MM, Erzen C. Cervical spondylotic myelopathy: surgical results and factors affecting prognosis. Neurosurgery. 1998;43(1):43-9; discussion 49-50.

19. Huang RC, Girardi FP, Poynton AR, Cammisa Jr FP. Treatment of multilevel cervical spondylotic myeloradiculopathy with posterior decompression and fusion with lateral mass plate fixation and local bone graft. J Spinal Disord Tech. 2003;16(2):123-9.

Autor za korespondenciju:

Dr Dragoslava Jovanovic Clinical Hospital Center Zemun, Vrtlarska Street 57, Belgrade, Serbia 